\title{
Biotransformation and bioaccumulation of arsenic by Brevibacillus brevis isolated from arsenic contaminated region of West Bengal.
}

\author{
Satabdi Banerjee ${ }^{1}$, Jayjit Majumdar ${ }^{1}$, Alok Chandra Samal ${ }^{1}$, Piyal \\ Bhattachariya $^{2}$ Subhas Chandra Santra ${ }^{1}$ \\ 1 Department of Environmental Science, University of Kalyani, West Bengal, India \\ 2 Department of Environmental Science, Kanchrapara College, Kanchrapara, West Bengal India
}

\begin{abstract}
Microorganisms influence the fate of metals in environment. Increasing anthropogenic and geogenic activity had increase the risk of arsenic pollution and this has forced the future research area to involve microbes-metal toxicity to achieve bioremediation. The present study deals with the role of arsenite transforming bacteria and incorporates them into remediation design. Sample was collected from Haringhata in Nadia district which is a known arsenic contaminated zone. Out of six isolated bacteria one bacterium revealed as arsenic tolerant bacteria which shows molecular similarity with Brevibacillus brevis from 16s rRNA studies. It can tolerate upto $1000 \mathrm{mg} / \mathrm{L}$ of arsenite and $500 \mathrm{mg} / \mathrm{L}$ of arsenate. Both the arsenic species has toxic effects on its protein concentration. The strains can tolerate upto a certain limit after that their growth ceased. This strain can accumulate and also transform arsenite to arsenate. The transformation capacity of strain was assessed qualitatively and quantitatively. The strain can transform $90 \%$ of arsenite to arsenate. But the transformation capacity only reveals as detoxification mechanism and has no relation with their respiration. Morphological biochemical and molecular identification was done. As arsenate is absorbed into iron oxyhydroxides and get immobilize thus a remediation mechanism can be designed with this strain.
\end{abstract}

Keywords: Arsenic, Bioaccumulation, Biotransformation, Bioremediation, Arsenic oxidising bacteria.

\section{Introduction:}

Arsenic contaminated in ground water has turned into the gravest catastrophe of nineteenth century specially encompassing Bangladesh, India (West Bengal), China, Taiwan, Vietnam, USA, Argentina, Chilli, Mexico etc [1]. Increasing dreadful concentration of arsenic in ground water of Bengal basin has been described as the greatest mass poisoning in human history. More than a million populations is badly affected [2]. Unfortunately such a dangerously contaminated ground water is the principal source of drinking water as well as irrigation water of this vast flood plain. Thus the entire array of human population and domestic animal living here is therefore compelled to this intake of poison day after day. Thus it is imperative to explore all possible means to combat such menace.

The mobilization of arsenic from soil to ground water depends on microbial activity [3].The exposure of microorganisms to toxic metals on early earth had helped to evolve several metal resistant mechanisms in them.Microorganisms plays an important role in arsenic mobilization by changing its oxidation state. Several microorganisms (bacteria, fungi, algae) had been reported which actively participates in arsenic biogeochemical cycle [4]. Some of the microorganisms are facultative where some are obligatory, as some metabolize arsenic for energy generation where some for detoxification [5]. The ecology of arsenic in environment depends on three mechanisms as methylation, oxidation and reduction [6]. Microbes conduct these three processes. The environmental impact of dissimilatory arsenate reducing prokaryotes (DARPS) has only recently been realized [7]. The reduction of arsenate is energetically favourable when coupled with oxidation of organic matter like lactate, malate, fumarate because the $\mathrm{As}(\mathrm{V}) / \mathrm{As}(\mathrm{III})$ oxidation/reduction potential is $+135 \mathrm{mV}$ [8]. In a recent study in Taiwan two arsenate reducing bacteria, Pseudomonas stutzeri and Bacillus cereus were isolated and they can transform $\mathrm{As}(\mathrm{V})$ to $\mathrm{As}(\mathrm{III})$ from lower arsenate concentration $(100 \mu \mathrm{g} / \mathrm{L})$ to higher arsenate concentration $(750 \mu \mathrm{g} / \mathrm{L})[9]$.

The process of dissimilatory $\mathrm{As}(\mathrm{V})$ reduction occurring in near surface hyporheic zones greatly affects the transport and speciation of arsenic in fresh water streams. But the detoxification of arsenic only relates with arsenite oxidation where arsenite transfers into arsenate which is less toxic. Interest in this subject has resulted in the recent isolation of several novel species of heterotrophic and autotrophic aerobic As (III) oxidizers from arsenic rich environment [10]. Girhing and Banfield [11] isolated a thermophilic species of Thermus( strain HR 13) from an As - rich hot spring The physiological role of arsenite oxidizers had been reported in well known organism Alcaligenes faecalis [12]. Physiologically diverse arsenite oxidizers involve both heterotrophic and chemolithoautotrophic group. Heterotrophic oxidation of As (III) is viewed primarily as a detoxification 
reaction that converts As(III) encountered in the cells outer membrane into less toxic form As(V) [7]. Chemolithoautotroph arsenite oxidizers couple the oxidation of arsenite to the reduction of either oxygen or nitrate and use the energy derives to fix $\mathrm{CO}_{2}$ into the organic cellular matter and achieve growth [8]. Several species like Thermus (strain HR 13) and Ectothiorodospira clade of Eubacteria had been identified as arsenite oxidizers. Recently As (III) oxidation has been identified in some more bacteria including Pseudomonas [13], Alcaligenes [14], Thiomonas, Herminiimonas, Agrobacterium, Thermus thiomonas [13].

West Bengal is one of the most contaminated sites in India. Arsenic sedimentation in Bengal delta basin is from Pleistocene and Holocene era [15] and this contamination spreads by both anthropogenic and geogenic reasons .Total $88,750 \mathrm{~km}^{2}$ in West Bengal has been identified as arsenic contaminated zone among which, $861 \mathrm{~km}^{2}$ areas has been identified as Highly affected zones this include Nadia, North and South 24 Paraganas, Murshidabad and Kolkata districts [16].In West Bengal most crop fields are contaminated with arsenic rich irrigated water [17]. Arsenic makes its way from crop fields to food chain. Arsenic is inflowing in 50 million people by contaminated water only [18]. Thus a critical measure is needed to stop this menace.

Use of micro organisms in arsenic ecology is being carried out all over the world. Several arsenic resistant bacteria were found from Taiwan [19], Bulgaria [20], USA [8], and China and from other places. Suresh et al (2004) isolated another arsenic resistant bacteria Deinococcus indicus from Chakdah in West Bengal [21]. Shivaji et al (2005) isolated a novel strain Bacillus arsenicus which can resist arsenic upto $20 \mathrm{mM}$ arsenate and $0.5 \mathrm{mM}$ arsenite [22]. The potential detoxification mechanism of arsenic detoxification of bacteria is related with ars genotype [23, 24]. The ars genotype is greatly diversed. It is reported that arsenite oxidizing bacteria Pseudomonas putida OS-3 (AY952322), which has arsB genes, and Agrobacterium tumefaciens, which has a signal transduction system composed of $a o x \mathrm{~S}-a o x \mathrm{R}-a \circ x \mathrm{~A}-a o x \mathrm{~B}-c y t c 2$, have been isolated from arseniccontaminated water and soil [25].

Thus this study will be helpful to characterize the arsenite oxidizing bacteria from arsenic contaminated soil .As arsenate gets precipitate in iron compounds thus it will immobilize the arsenic species and reduce the arsenic contamination. This present study can help to form a management mechanism can be adopted in arsenic affected areas to minimize the arsenic mobilization and contamination in soil.

\subsection{Study area and Sampling:}

\section{Materials Methodology:}

Surface soil samples $(0-15 \mathrm{~cm})$ were collected in three random replicates from crop fields of Saontalpara village in Haringhata of Nadia district (Fig 1). In previous studies this location is reported as arsenic prone zone, as it appears that the groundwater of entire seventeen blocks of Nadia district contains arsenic above WHO guideline value of arsenic in drinking water $(10 \mu \mathrm{g} / \mathrm{L})$ and Indian Standard value $(50 \mu \mathrm{g} /)$ [26].

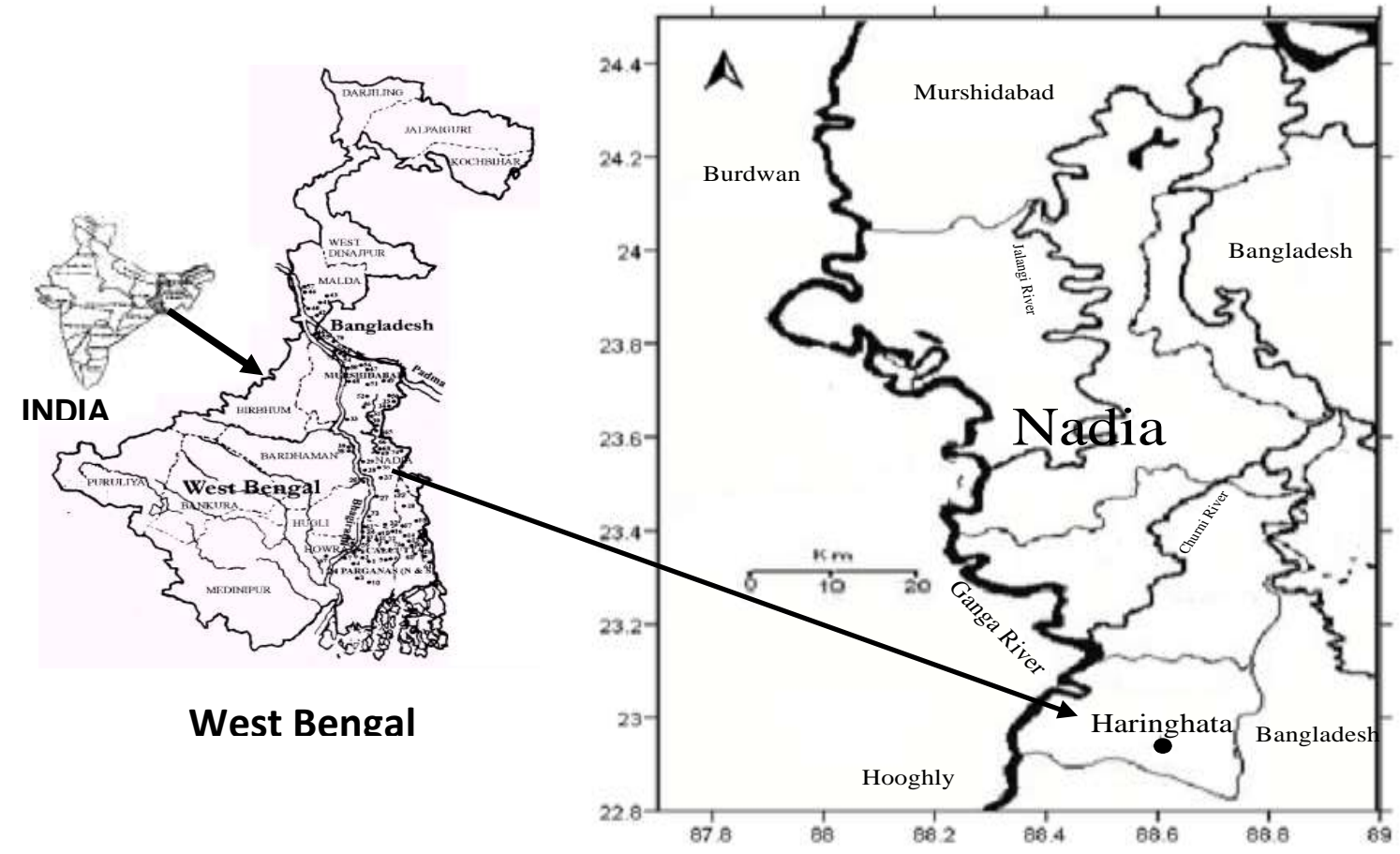

Figure 1. Map of study site

Haringhata block, Nadia district. 


\subsection{Soil Analysis:}

$\mathrm{pH}$ of soil sample was measured by Electrometric method with the help of a $\mathrm{pH}$ meter using combination Glass electrode. Organic Carbon was done by Walkley and Black method [27]. Chloride, Nitrate, Phosphate, Sodium and Potassium content were estimated by methods prescribed by APHA [28]. The total nitrogen content was estimated by Kjeldahl method (APHA 1992). The samples were digested following heating block digestion procedure for Arsenic measurement [26]. The amount of arsenic was estimated by Atomic absorption Spectrophotometer (Perkin Elmer, Analyst 400) accompanied with hydride generation system [29].

\subsection{Isolation of arsenite resistant Bacteria:}

The bacterial strain was isolated in iron bacteria isolating media containing Diammonium sulphate $(0.5 \mathrm{gm})$, glucose $(0.15 \mathrm{gm})$, Calcium Carbonate $(0.1 \mathrm{gm})$, Dipotassium hydrogen phosphate $(0.05 \mathrm{gm})$, Magnesium sulphate, $2 \mathrm{H}_{2} 0(0.05 \mathrm{gm})$, Potassium chloride $(0.05 \mathrm{gm})$, Calcium nitrate $(0.01 \mathrm{gm})$, thiamine $(0.4$ $\mathrm{mg} / 5 \mathrm{ml})$, Cyanocobalamin $(0.01 \mathrm{mg} / 5 \mathrm{ml})$, Agar $(15.0 \mathrm{gm})$ in $1000 \mathrm{ml}$ of distilled water, $\mathrm{pH} 7.0$. The plates were allowed to incubate at $37^{\circ} \mathrm{c}$ for 24 hours. Pure culture was obtained by subculture and pure culturing technique from the isolated colonies [20].

\subsection{Determination of Minimum Inhibitory Concentration of Arsenic:}

Cup assay method was used to determine the maximum tolerable concentration of the strains for both arsenate and arsenite [20].Apart from arsenic minimum inhibitory concentration was also determined for mercury and cadmium.

\subsection{Determination of Growth response for Arsenite and Arsenate:}

The bacteria were grown in both arsenate and arsenite containing iron bacteria isolating broth media. The media contained $20 \mathrm{mg} / \mathrm{L}, 50 \mathrm{mg} / \mathrm{L}, 100 \mathrm{mg} / \mathrm{L}, 500 \mathrm{mg} / \mathrm{L}$ and $1000 \mathrm{mg} / \mathrm{L}$ concentrations of arsenate and arsenite within their tolerable limit .It was incubated at $37^{\circ} \mathrm{c}$ for 24 hours. Optical density was measured at 420 $\mathrm{nm}$ at alternate days for at least 7 days [20].

\subsection{Determination of Bioaccumulation of Arsenic:}

Arsenic can be stored intercellular, called bioadsorption. Bacterial strain was grown on arsenic containing media and $1 \mathrm{ml}$ of media containing biomass was separated in alternate days. The media was centrifuged at 10,000 rpm for $5 \mathrm{~min}$ to separate the media and biomass. The supernatant and residue was isolated. Nitric acid was added to the samples for sample digestion. The samples were heated till they become colorless. The samples were then diluted with distilled water into $10 \mathrm{ml}$. The arsenic content was then measured by Atomic Absorption Spectrophotometry [30].

\subsection{Identification of the Bacterial Strains: \\ 2.7.1 Morphometric Identification}

Gram staining and cell morphology was investigated under microscope (1000x) [20]. Biochemical properties of the isolates were tested by following, Catalase test, Citrate utilization test, Methyl Red test, hydrogen sulfide test, Starch hydrolysis test, Carbohydrate Fermentation test, and Vogues Proskauer test [31] for identification.

\subsubsection{Isolation of Genomic DNA}

DNA extraction from the bacterial strain was performed using, Genei DNA isolation kit (KT 159L) according to OHBA (2005) [32]. Each bacterium was transferred to liquid growth medium and incubated for 48 hours. Pellets were collected from $1.5 \mathrm{ml}$ of bacterial cultures. Briefly the pellet was suspended in $100 \mu \mathrm{L}$ of Bacterial lysis buffer and incubates for $30 \mathrm{~min}$ at $37^{\circ} \mathrm{c}$.After that $20 \mu \mathrm{L}$ of Proteinase $\mathrm{K}$ and $180 \mu \mathrm{L}$ of lysis buffer I was added and incubate for 3 hours at $55^{\circ} \mathrm{c}$. Centrifuged were done and $4 \mu \mathrm{L}$ of RNase A and $200 \mu \mathrm{L}$ of lysis buffer II was added to the supernatant. Then absolute alcohol was added. After adding the wash buffers the complete removal of ethanol was done at $70^{\circ} \mathrm{c}$ in a dry bath. Finally the DNA was dried and dissolved in pre warmed elution buffer. The suspension was used as DNA template for subsequent PCR amplification.

\subsubsection{PCR amplification of 16s ribosomal rRNA}

The metagenomic DNA was used for PCR amplification of the 16S rRNA gene, by using specific 8UF primers (5'- AGA GTT TGA TCM TGG CTC AG - 3') and 519B - R (5'-GTA TTA CCG CGG CGG CKG CTG -3'). PCR reaction contained PCR $6 \mu \mathrm{L} 10 \mathrm{X}$ buffer (20mM Tris- $\mathrm{HCl}$ ( $\mathrm{pH} 8.4$ ), $50 \mathrm{mM} \mathrm{KCl}), 3 \mu \mathrm{L} \mathrm{MgCl}, 5$ $\mu \mathrm{L}$ initiator dNTP, $1 \mu \mathrm{L}$ Taq DNA polymerase (InvitrogenTM, São Paulo, Brazil) and $4 \mu \mathrm{L}$ template DNA, in a final volume of $40 \mu \mathrm{L}$. Samples were then placed in a thermal cycler for amplification of the gene [32]. The 
$1.5 \mathrm{~Kb}$ amplicons were analyzed through electrophoresis and removed from the gel ( $1 \%$ agarose gel) through gel purification kit (Genei, Pl.No.KT02) [32].

\subsubsection{Analysis of Sequence Data}

The NCBI BLAST program was used to analyze the sequence data of the isolate. Distance analysis and phylogenetic tree construction were performed using the neighbor joining method (NJ) of MEGA vers5.

\subsection{Determination of the effect of arsenic on protein concentration of the isolated bacteria:}

The culture was incubated at $30^{\circ} \mathrm{C}$ for $24 \mathrm{~h}$ and cells were harvested by centrifugation at $14000 \mathrm{rpm}$ for $10 \mathrm{~min}$, washed twice in $50 \mathrm{mM}$ phosphate buffer $(\mathrm{pH} 7)$ and re suspended in $5 \mathrm{ml}$ of $50 \mathrm{mM}$ phosphate buffer (pH7).Cells were disrupted by sonication for $15 \mathrm{sec}$ and centrifuged at $14000 \mathrm{rpm}$ for $1 \mathrm{~h}$ at $4^{\circ} \mathrm{C}$. The pellet resuspended in $50 \mathrm{mM}$ phosphate buffer $(\mathrm{pH} 7)$ represents the membrane fraction while the supernatant represents the soluble fraction. The protein concentration was estimated by the Lowry method after hydrolysis of the cells in $0.4 \mathrm{~N} \mathrm{NaOH}$ at $100{ }^{\circ} \mathrm{c}$ for $10 \mathrm{~min}$. Bovine serum albumin was used as standard [20]

\subsection{Determination of Transforming Ability of the isolated Bacteria:}

The verification of the transforming ability of the isolated bacteria was carried out by the usage of $\mathrm{AgNO}_{3}$ method. Agar plates were flooded with a solution of $0.1 \mathrm{M} \mathrm{AgNO}_{3}$. A brownish precipitate revealed the presence of arsenate in the medium (arsenite oxidizing bacteria), while the presence of arsenite was detected by a bright yellow precipitate (arsenate reducing bacteria) [20]. The abilities of the bacterial isolates to oxidize As (III) or reduce As (V) were further quantitatively determined. Bacterial isolate was treated with $50 \mathrm{mg} / \mathrm{L}$ of arsenite solution and after $48 \mathrm{~h}$ of incubation, the bacterial culture was centrifuged and arsenic species were measured by Atomic Absorption Spectrophotometer followed by Mercury Hydride Generation System. Speciation was done by using $0.2 \mathrm{M}$ Citric acid as carrier solution and $0.4 \%$ sodium borohydrate as reductant. In this process only arsenite was detected. The total arsenic was measured with $10 \%$ Hydrochloric acid as carrier solution and $0.4 \%$ sodium borohydrate as reductant [33]. The amount of arsenate was calculated from the two values and the transforming capacity was presented in percentage. The quantitative transformation test was further analysed with different incubation time. As the strains were inoculated with $50 \mathrm{mg} / \mathrm{L}$ of arsenic dose and incubated. The first batches were incubated for 24 hours, second batch for 48 hours and third batch for 72 hours. The test was done in replicates and arsenic species were measured by Atomic Absorption Spectrophotometer with the help of above method.

\subsection{Statistical analysis:}

All experiments were done in triplicates and results are presented in mean value with standard deviation.

\subsection{Physicochemical characteristics of Soil:}

\section{Results:}

Some selected physicochemical characteristics of soil sample were ascertained. The $\mathrm{pH}$ content was alkaline. Organic Carbon was $1.2( \pm 0.15) \%$. Chloride content was $7.1( \pm 0.12) \mathrm{mg} / \mathrm{kg}$. Nitrate and phosphate content were low as $0.57( \pm 0.02) \mathrm{mg} / \mathrm{kg}$ and $0.35( \pm 0.03) \mathrm{mg} / \mathrm{kg}$ respectively. The Sodium and potassium amount were $9.4 \mathrm{mg} / \mathrm{kg}$ and $4.6 \mathrm{mg} / \mathrm{kg}$ respectively. Arsenic content is high as $7.3( \pm 0.02) \mathrm{mg} / \mathrm{kg}$ and Nitrogen content is low $0.57( \pm 0.02) \mathrm{mg} / \mathrm{kg}$.

\subsection{Isolation of Metal resistant Bacteria:}

Six aerobic bacterial isolates were obtained in iron bacteria isolating media. Out of which one strain $\left(\mathrm{S}_{1}\right)$ revealed as arsenic resistant bacteria when grown in different arsenite and arsenate containing media. The cup assay test was done and it was found that the strain $S_{1}$ can tolerate arsenite $1000 \mathrm{mg} / \mathrm{L}$ and $500 \mathrm{mg} / \mathrm{L}$ for arsenate.

\subsection{Multiple Metal resistances:}

For mercury and Cadmium the strain can grow upto $300 \mathrm{mg} / \mathrm{L}$. Thus among these three metals bacterial strain showed highest tolerant characteristics for arsenic.

\subsection{Arsenic Tolerance test:}

The strain can tolerate higher concentration of arsenate $(500 \mathrm{mg} / \mathrm{L})$ and arsenite $(1000 \mathrm{mg} / \mathrm{L}) . \mathrm{S}_{1}$ strain showed highest growth rate in case of $100 \mathrm{mg} / \mathrm{L}$ of both arsenite and arsenate containing media. $\mathrm{S}_{1}$ strain can grow in arsenate containing media upto $7^{\text {th }}$ day but after $5^{\text {th }}$ day their growth decreases (Fig 2). The strain exhibit increased growth rate in arsenite up to $7^{\text {th }}$ day. After $5^{\text {th }}$ day the growth rate decreases of all concentrations. So the growth rate of the strain does not differ with incubation time for both the arsenite and arsenate containing 
media. It varies with the arsenic species as growth rate in arsenite containing media is much higher than in arsenate containing media (Fig $2 \& 3$ ). The growth rate also varies with different concentrations as growth rate increases with increasing concentration but after $100 \mathrm{mg} / \mathrm{L}$ the growth rate decreased in both factors. This result suggested that the strain has developed metal resistant systems in an attempt to protect sensitive cellular components. In general, microbial ability to grow at high metal concentration is found coupled with a variety of specific mechanisms of resistance and environmental factors. Mechanisms, of resistance by microorganism include microbial surface sorption, enzymatic transformation, and precipitation by oxidation/reduction reaction and biosynthesis of metal binding proteins or extracellular polymers; whereas environmental factors may include the surrounding $\mathrm{pH}$ and redox potential, metal speciation, soil particulates and soluble organic matters.

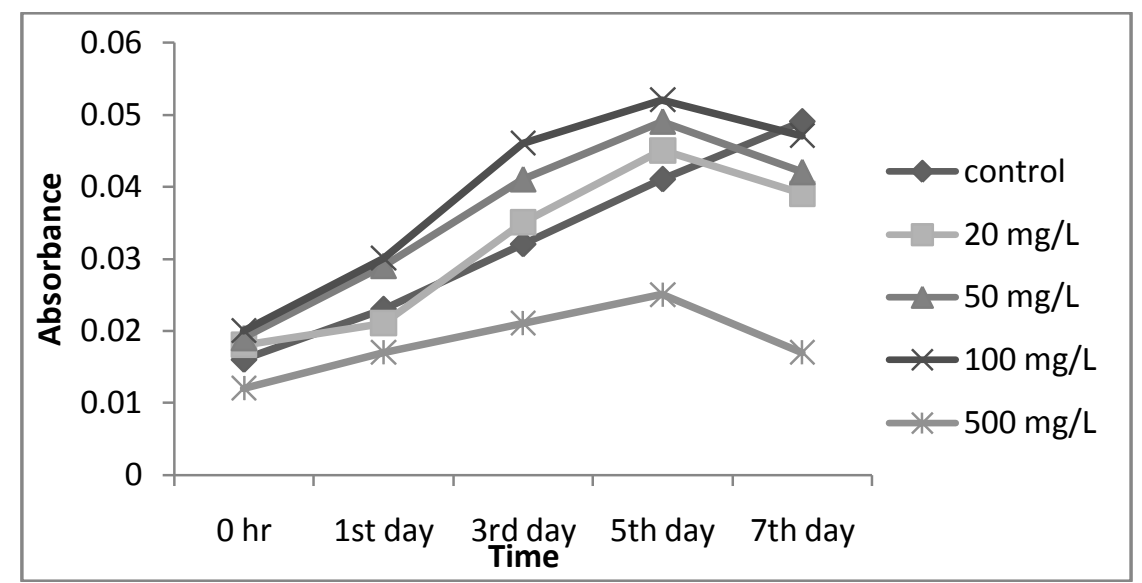

Figure 2. Growth response of $S_{1}$ strain for As (V)

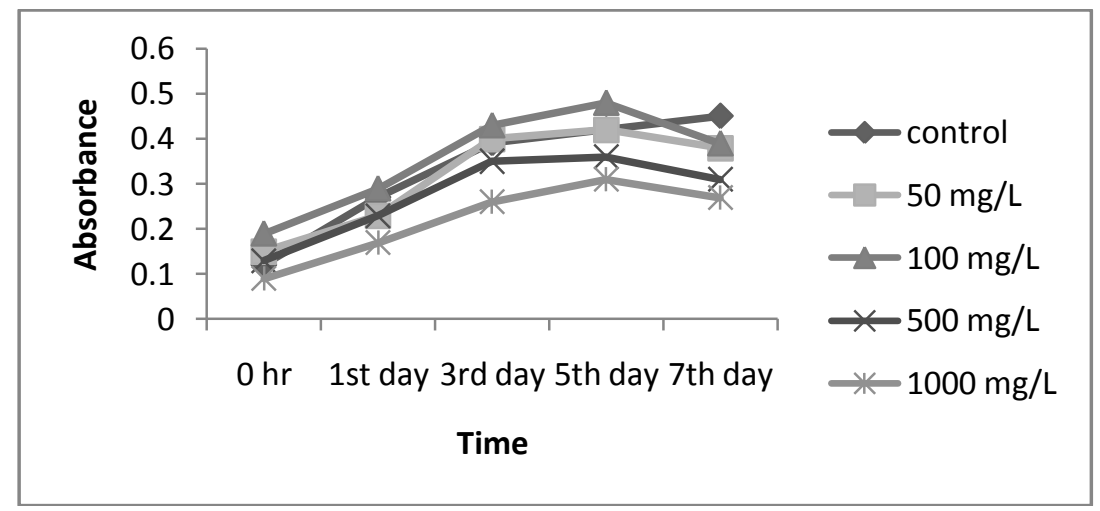

Figure 3.Growth Response of $\mathrm{S}_{1}$ strain for As (III)

\subsection{Effect of arsenic on Protein Concentration:}

Arsenite has effect on the protein concentration of the strain. From the Fig 4, it is exhibited that with increased dose of arsenite the protein concentration of the strain decreased. The protein concentration also decreased with increased incubation time. Arsenate has more effect than arsenite (Fig 5) as the protein concentration is less in case of arsenate treated samples. The results of this study support the growth response of the strain against arsenite and arsenate containing media. Thus from these two analysis it is revealed that the arsenate has more toxic effect on this strain than arsenite. The defence mechanism can resist upto a certain incubation time. Also after $500 \mathrm{mg} / \mathrm{L}$ of concentration the strain failed to respond. The strain thrives successfully in controlled condition. 


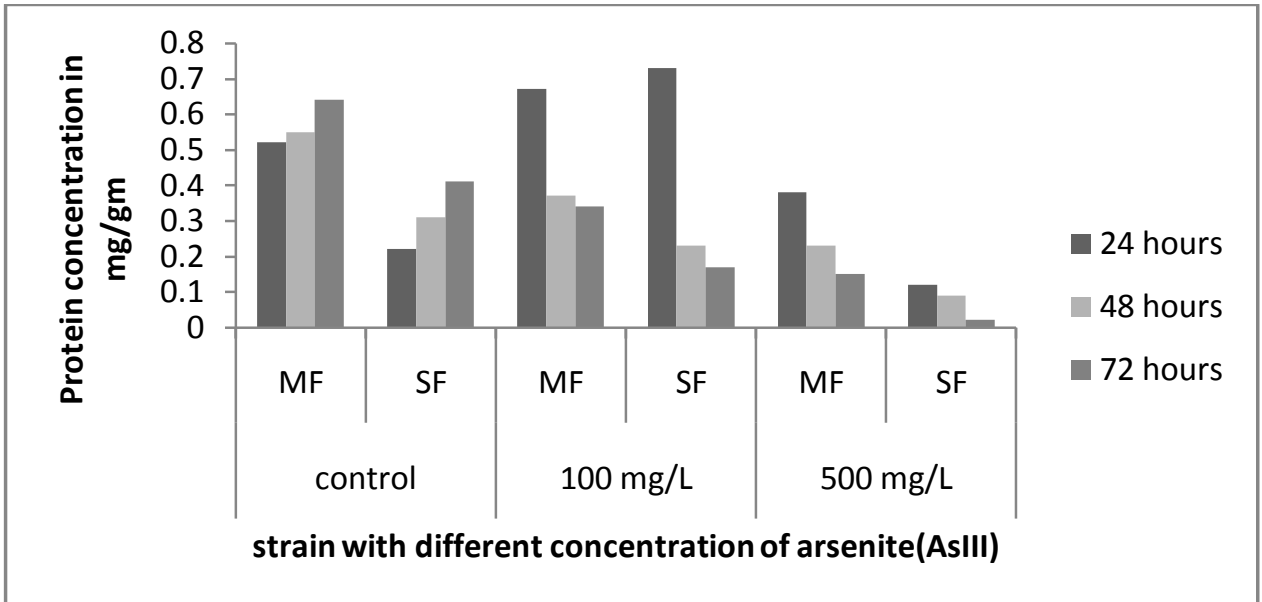

Figure 4. Effect of arsenite on protein concentration

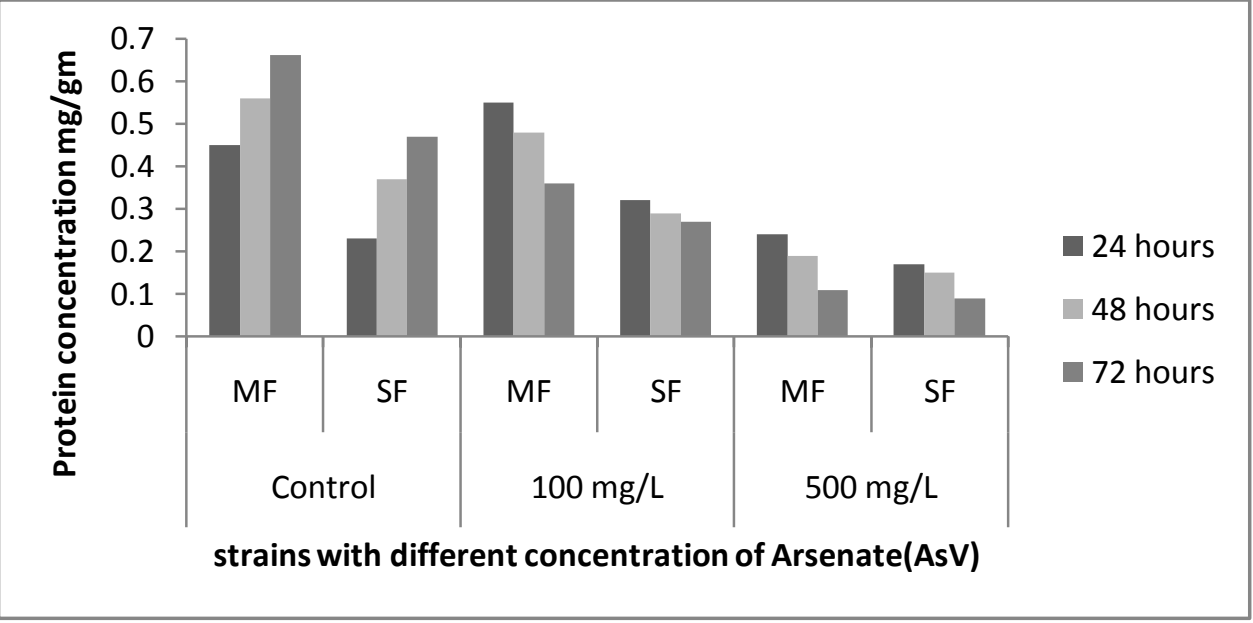

Figure 5. Effect of arsenate on protein concentration.

\subsection{Arsenic Bioaccumulation Test:}

From $50 \mathrm{mg} / \mathrm{L}$ of arsenic concentration the strain accumulate $24.8 \mathrm{mg} / \mathrm{L}$ of arsenic after 24 hours. The accumulation amount decreased after 48 hours to $18.9 \mathrm{mg} / \mathrm{L}$ (Fig 6). Again the accumulation increases after 72 hours at $27.1 \mathrm{mg} / \mathrm{L}$. Thus the strain can accumulate $50 \%$ of total arsenic from arsenic containing media.

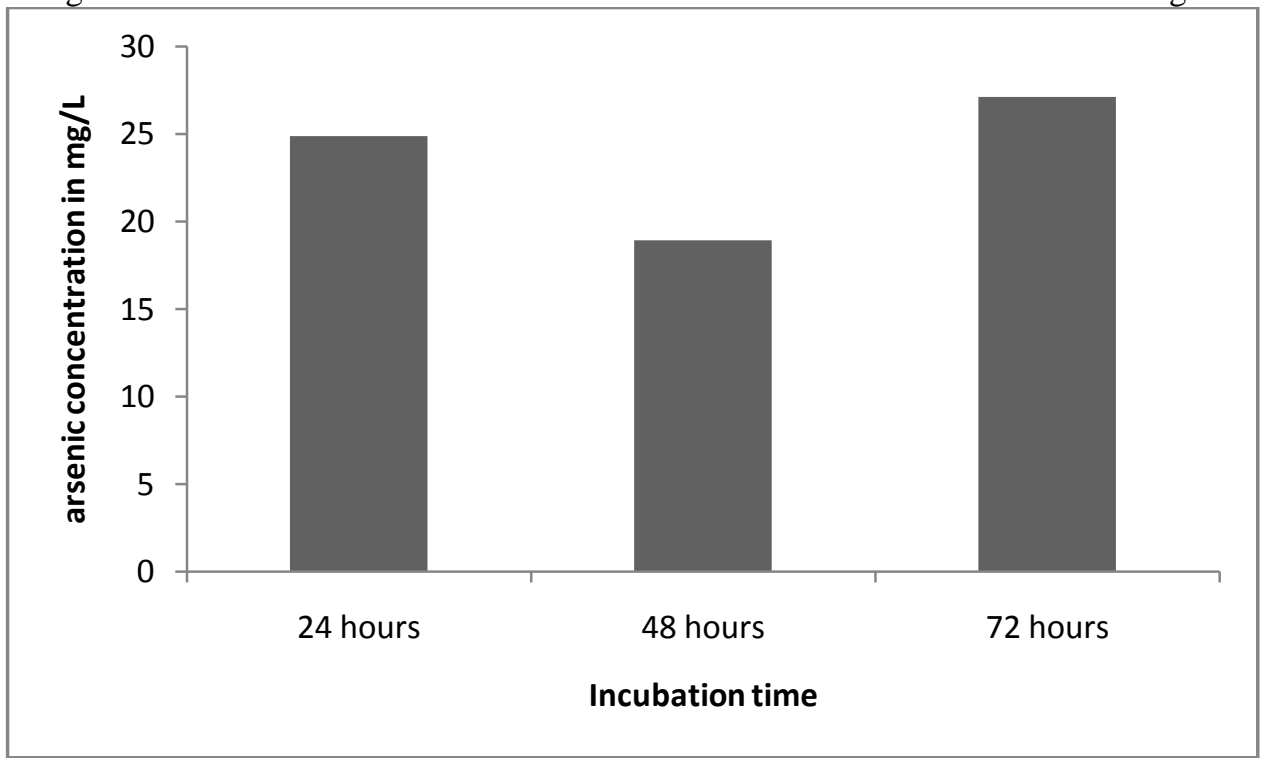

Figure 6. bioaccumulation of arsenic with different incubation time 


\subsection{Arsenic Transformation Test:}

In the present work, the isolates were tested with $\mathrm{AgNO}_{3}$ test. The silver nitrate test is based on the quality reaction between $\mathrm{AgNO}_{3}$ and arsenite or arsenate ions. The interaction of $\mathrm{AgNO}_{3}$ with $\mathrm{As}[\mathrm{III}]$ generates bright yellow precipitate and $\mathrm{As}[\mathrm{V}]$ generates brownish precipitate. In this study the resulting precipitates containing Arsenic were coloured light brown red of $\mathrm{Ag}_{3} \mathrm{AsO}_{4}$ (silver orthoarsenate) due to presence of Arsenate $\mathrm{As}(\mathrm{V})$ (Fig 7).Thus the isolate $\left(\mathrm{S}_{1}\right)$ revealed as arsenite oxidizing bacteria. The strain was revealed as arsenite oxidizing bacteria.

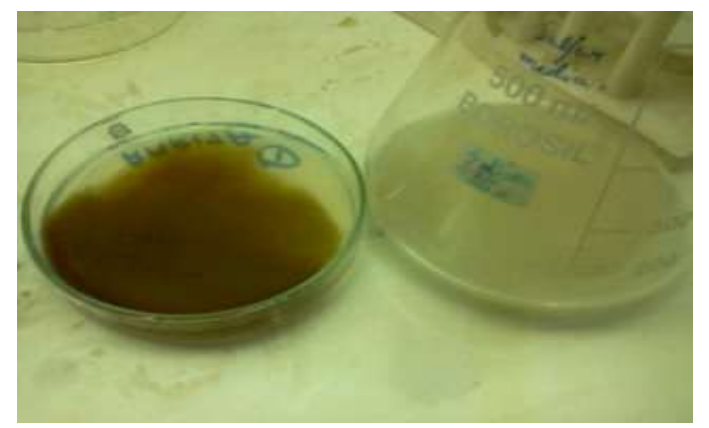

Figure 7. Brown precipitate indicates presence of arsenate

Further the arsenic transforming capacity was tested quantitatively with the help of Atomic Absorption Spectrophotometer.

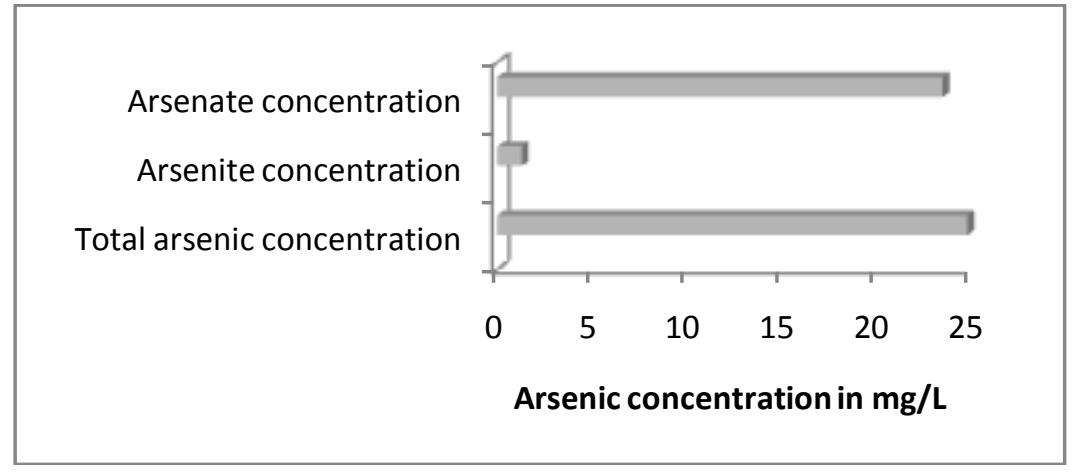

Figure 8. Transforming capacity of Strain $\mathbf{S}_{1}$

It was found that the total arsenic concentration was $24.88 \mathrm{mg} / \mathrm{L}$ and arsenite concentration was $1.304 \mathrm{mg} / \mathrm{L}$. This results exhibit that the arsenate value is $23.57 \mathrm{mg} / \mathrm{L}$ i.e. the transformation capacity of the strain is $94.73 \%$ (Fig 8).Further the transformation capacity of the strain was assessed with different incubation time (Fig 9). The transformation capacity first decreased at 48 hours then increased after 72 hours. After 24 hours the transformation capacity was $94 \%$ after that it decreased to $88 \%$ and then again after 72 hours it again increased to $90 \%$.

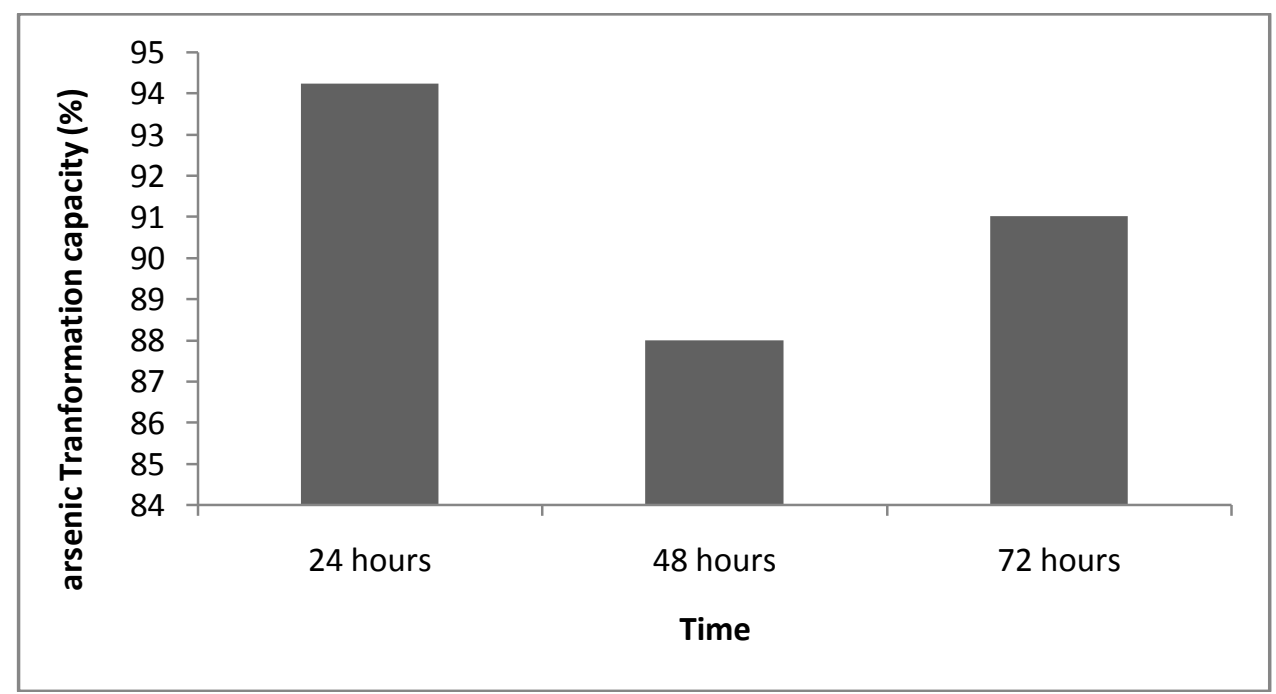

Figure 9. Transforming capacity of strain $S_{1}$ with different incubation time 


\subsection{Identification of the strain}

Morphological, and biochemical characteristics of the bacterium was evaluated. $S_{1}$ strain is Gram positive, rod in nature. The strain shows positive result for Catalase test and starch hydrolysis test. Whereas it shows negative result for citrate utilization test, MR-VP test, Hydrogen sulphide test. Confirmation of the taxonomical status was confirmed by molecular method. To confirm the species, the partially amplified fragment $(600 \mathrm{bp})$ of $16 \mathrm{~s}$ rRNA gene was uploaded to NCBI website (National Centre for biotechnology Information). From the blast results it is revealed that this gene is $98 \%$ homologous to Brevibacillus brevis NBRC 100599. The other closely related species are Bacillus coagulans, Geobacillus thermoglucosidasius C56_YS93. The phylogenetic tree for the isolated arsenic transforming bacterium and their close relatives is shown in Fig 10.

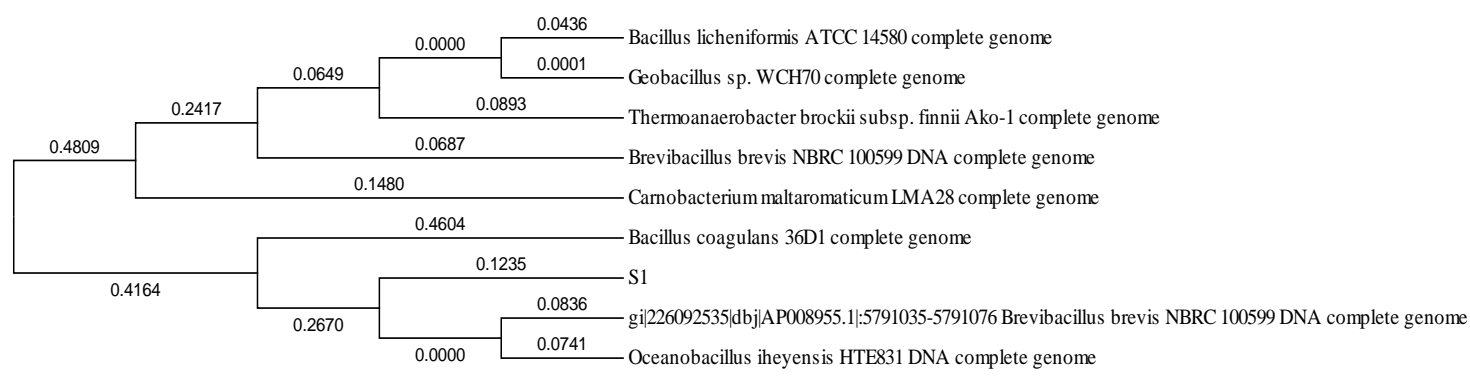

Figure .10 phylogenetic tree of the strain $S_{1}$

\section{Discussion}

Arsenic pollution in the Nadia district is hardly affected. Utmost places of this districts have arsenic concentration in ground water and soil above WHO permissible value [16] .Quite a few studies were carried out with arsenic flow in food chain but there is a lack of studies in microbial role in arsenic ecology in this area [29]. As a consequence we investigated the role of arsenic resistant bacteria in soil.

The mobility of arsenic depends on certain factors those are soil solution chemistry, $(\mathrm{pH}$ and redox condition), solid composition, arsenic bearing phases, adsorption and desorption, biological transformation, volatilizations and cycling of arsenic [34]. In recent era use of microbial metabolism for bioremediation is a useful tool. A microbial metabolism includes the biochemical reactions or pathways to uptake and circulates the metal [8]. A number of microbes can uptake and transform arsenic in environment. Arsenate reduction and subsequent arsenite efflux are common in Archea, bacteria and fungi [35]. But the roles of arsenite oxidizing bacteria are important because they take part in detoxification mechanism.

In this study the soil of Haringhata contains $7.3 \mathrm{mg} / \mathrm{kg}$ of arsenic. This reveals that the soil contain high amount of arsenic. The strain can tolerate $1000 \mathrm{mg} / \mathrm{L}$ of arsenite solution and $500 \mathrm{mg} / \mathrm{L}$ of arsenate solution. Under reducing condition arsenite can be the predominant arsenic species and generally less retained by the soil colloids [36]. As the flooded soil like rice field has the same condition so it can be assume that the strains isolated from the study field can tolerate more arsenite than arsenate. It can also tolerate other toxic metals like mercury $(300 \mathrm{mg} / \mathrm{L})$ and lead $(300 \mathrm{mg} / \mathrm{L})$. These results indicate that the strain has developed some mechanism against the toxic effect of the metal. The strain not only binds the metal in the outer membrane but also it intake the metal and transforms its state. Although the uptake of metals impede to a certain concentration. $\mathrm{S}_{1}$ strain can tolerate $1000 \mathrm{mg} / \mathrm{L}$ of arsenite solution but after $500 \mathrm{mg} / \mathrm{L}$ its growth ceases drastically and toxic effects are prominent. As the protein concentration of the strain decreased at $500 \mathrm{mg} / \mathrm{L}$. As arsenite binds with the sulfhydryl groups of protein and disrupts its function. Thus in this study the strain can tolerate up to $500 \mathrm{mg} / \mathrm{L} \mathrm{of}$ arsenite. The strain can also accumulate $50 \%$ of total arsenic from arsenic containing media. The accumulation capacity decreased first then again increased after 72 hours of incubation. This result supports the results of transformation capacity with incubation time. In that case also first the transformation capacity decreased after 48 hours then again increased after 72 hours.

$\mathrm{S}_{1}$ strain can oxidize arsenite to arsenate. As the strain can also showed high growth rate without arsenic and with carbon source this indicates that the strain is not chemolithoautotroph. Here the arsenic transformation only relates with detoxification mechanism. The detoxification mechanism occurs under aerobic condition. When quantitatively assessed the strain can transform $90 \%$ of arsenite to arsenate. As in the same process Alcaligenes faecalis, reported arsenite oxidizer, was assessed which can transforms $80 \%$ of arsenite to arsenate. When the transformation capacity was assessed against time it showed that at 24 hours of incubation the transformation rate is highest which decreased at 48 hours and again increased at 72 hours. This result indicates that the transformation rate is not same and it depends on some other condition. Oxidation of arsenite is done by a periplasmic enzyme arsenite reductase [19]. Thus the uptake of arsenite followed by production of arsenite oxidase and release of arsenate from the cell is not same at all incubation time. But it is clear from this 
study that the transform of arsenite through this enzyme creates a potential detoxification process which allows the strain to tolerate higher level of arsenite. Thus it can't resist higher level of arsenate.

Till now several arsenite oxidizing bacteria has been reported. Physiologically diverse some are heterotrophic arsenite oxidizers and some are chemolithoautotrophic arsenite oxidizers. The mechanism behind the detoxification system was identified using the chromosome and plasmid encoded ars operon [23]. The two most common types of these operons contain either five (arsRDABC) or three (arsRBC) genes [25,13].All these reported strains can tolerate high amount of arsenite and can transform it to arsenite. Thus the results of this study were supported by other previous reported reports.

The strain in this study was revealed as from Bacillus genus. Previously many arsenic resistant bacteria were reported from Bacillus genus. Bacillus and Pseudomonas are two widely known groups for arsenic resistant bacteria [25]. Various studies were carried out to isolate arsenic resistant bacteria from estuary [37], groundwater [19],coastal sea water [25], waste water [38].Till now all the studies indicates that arsenic resistance and also transforming bacteria are widely distributed and phylogenetically diverse [19]. But in this study the closely relatives species of this strains are not reported.

In this study the strain is concerned with only the detoxification mechanism. This is the basis of bioremediation system as arsenite is more toxic and arsenate can immobilized into strong adsorbents. With the help of this strain we can build a remediation strategy. But further study is required for the genomic structure behind the detoxification mechanism. As this bacterium is an indigenous one and isolated from the most contaminated soil of one of the most contaminated area (Nadia) of West Bengal. Thus this strain can light up the microbial ecology of arsenic in this area. Like $S_{1}$ strain can oxidize the arsenite into arsenate and immobilized it in any strong adsorbents but anoxic environment again activates the dissimilatory arsenate reducing prokaryotes thus again arsenate can be reduced to arsenite and solubilise into water. Thus any remediation strategy with arsenite oxidizing bacteria needs strong aerobic environment as microbe arsenic interaction depends on a number of soil physical characteristics.

\section{Conclusion:}

Many theories have been postulated regarding release of arsenic in ground water .But arsenic pollution still threatening the Bengal delta plain. The role of microbes in arsenic ecology is also being studied since these decades. In context with this our attempt was to isolate some arsenic resistant bacteria from crop field as crop field are the most contaminated sites in Bengal. The isolated strain was found from Bacillus genus. It is well adapted to arsenite and arsenate environment. The strain can also transform arsenite to less toxic arsenate .Further information will be needed to characterize its genotypic character and presence of arsenic resistant gene. This information is useful to prepare remediation strategies with indigenous microbial communities from contaminated sites.

\section{Acknowledgements:}

This investigation is funded by the grants from Purse Programme of DST, Govt. of India. Authors are grateful to Department of Environmental Science, University of Kalyani for providing laboratory and other facilities.

\section{References:}

[1] H Brammer., Threat of Arsenic to Agriculture in India, Bangladesh and Nepal, Economic and Political Week l. 43(47),2008, 79-84.

[2] P. Ravenscroft, W.G. Burgess, KM Ahmed, M Burren, J.Perrin. Arsenic in groundwater of the Bengal Basin, Bangladesh: distribution, field relations and hydrogeological setting. Hydrogeology J, 13, 2009, 727-51.

[3] W. P.Inskeep, T. R. McDermott and S. Fendorf, Arsenic(V)/(III) cycling in soils and natural waters: chemical and microbiological processes, Environmental chemistry of arsenic. Marcel Dekker, Inc., New York, N.Y. 2002, 183-215

[4] A. Smith, P. Lopipero, M. Bates, C. Steinmaus, Arsenic epidemiology and drinking water standards. Science. 296, 2002, 2145-2146

[5] A.H. Ahmann, L.R. Krumholz, H.F. Hemond, D.R Lovley, and F.M.M Morel, Microbial mobilization of arsenic from sediments of the Aberjona watershed. Environ Sci Technol 31, 1997, 2923-2930

[6] J. F Stolz, and P. Basu, Evolution of nitrate reductase: Molecular and structural variations on a common function, Chem Bio Chem, 3, 2002, $198-206$.

[7] R. S Oremland, J. F Stolz, D. J. Ellis, Microbial transformation of element:arsenic, Int. J.Syst. Bacteriol. 49,2002, 305-308.

[8] J.P Maity., S. Kar, J.H. Liu, J. S. Jean, C.Y. Chen, J. Bundschuh, S. C. Santra and C. C. Liu, The potential for reductive mobilization of arsenic [As(V) to As(III)] by $\mathrm{OSBH}_{2}$ (Pseudomonas stutzeri) and $\mathrm{OSBH}_{5}$ (Bacillus cereus) in an oil contaminated site. Journal of Environmental Science and Health part a, 46:11, 2011, 1239-1246.

[10] T. M Salmassi, K Venkateswaren, M, Satmomi, KH. Nealson, D.K Newman, J.G Hering, Oxidation of arsenite by Agrobacterium albertimagni, AOL15, sp. Nov., isolated from Hot Creek, California. Geomicrobiology Journal 19, 2002,53 - 66.

[11] T. M Gihring, G. K Druschel, R. B McCleskey, R. J Hamers. \& J. F Banfield, Rapid arsenite oxidation by Thermus aquaticus and Thermus thermophilus: field and laboratory investigations. Environ Sci Technol 35, 2001, 3857-3862.

[12] J.R Lloyd, D.A. Klessa., D.L Parry, P Buck., N.L Brown, Stimulation of microbial sulphate reduction in a constructed wetland: microbiological and geochemical analysis. Water Res. 38, 2004, 1822-1830

[13] C. Lin, G. Liu, C. Rensing and G. Wang, Molecular Investigation of Arsenic Transforming Bacteria. BMC Microbiology, $10.1186,2009,1471-2180$ 
[14] K. Duquesne, A. Lieutaud, J. Ratouchniak, D. Muller, M-C Lett, V Bonnefoy. Arsenic oxidation by a chemoautotrophic moderately acidophilic Thiomonas sp.: from the strain isolation to the gene study. Environ. Microbiol. 10(1), 2008, 228-237.

[15] S.K Acharya, S. Lahiri, B.C. Kaymahashay, A. Bhowmic .Arsenic toxicity in ground water in parts of Bengal Basin in India and Bangladesh: role of quaternary stratigraphy and Holocene sea level fluctuation. Environ Geol 39(10), 2000, 1127-1137

[16] D Chakraborti, B. Das, M. M Rahman, U. K Chowdhury, B. Biswas, A. B Goswami, B. Nyak, A Pal., M. K Sengupta, S. Ahmed, A Hossain, G Basu, T. Roychowdhury, D.Das. Status of Groundwater arsenic contamination in the state of West Bengal, India: A 20year study report. Molecular Nutrition and Food Research, 53(5), 2009, 542-551.

[17] M. J Abedin., S. Malcolm., A. Andy, J. Cotter-Howells, Arsenic Accumulation and Metabolism in Rice (Oryza sativa), Environ. Sci. Technol., 36, 2002, $962-968$.

[18] P.L Smedley, and D.G Kinniburgh, A review of the source, behaviour and distribution of arsenic in natural waters.Appl Geochem $17,2002,517-568$.

[19] L. Vivian Hsiu-Chuan, C. Yu-Ju, S. Yu-Chen, H. Sung-Yun, W. Chia-Cheng, L. Chen-Wuing, L. Chung-Min, S. Wei-Chiang, C.Fi-John. Arsenite-oxidizing and arsenate-reducing bacteria associated with arsenic-rich groundwater in Taiwan, Journal of hazardous material 2011 doi:10.1016/j.jhazmat.2011.09.099,

[20] K. Krumova., M. Nikolosova., V. Groudeva, Isolation and identification of arsenic-Transformating Bacteria from arsenic contaminated sites in Bulgaria, Biotechnol \& Biotechnol, 2001, 721-728.

[21] K. Suresh, S. R Prabagaran, S. Sengupta, \& S. Shivaji, Bacillus indicus sp. nov., an arsenic-resistant bacterium isolated from an aquifer in West Bengal, India. Int J Syst Evol Microbiol 54, 2004, 1369-1375.

[22] S Shivaji, N. S Rao, L. Saisree, G. S. N Reddy., G. Seshu Kumar, \&, P. M Bhargava.. Isolates of Arthrobacter from the soils of Schirmacher Oasis, Antarctica. Polar Biol 10, 1989, 225-229.

[23] S Silver. And L.T Phung A bacterial view of the periodic table:genes and proteins for toxic inorganic ions.J Ind Microbiol Biotechnol 32,2005, 587-605.

[24] R. Chowdhury, A. K. Sen, P. Karak, R. Chatterjee, A. K. Giri, K. Chaudury, Isolation and characterization of an arsenic-resistant bacterium from a bore-well in West Bengal, India Annals of Microbiology, 59 (2) ,2009, 253-258.

[25] J.S Chang, Y.H Kim, K.W Kim., The ars genotype characterization of arsenic-resistant bacteria from arsenic-contaminated goldsilver mines in the Republic of Korea. Appl. Microbiol. Biotechnol. 80, 2008, 155-165.

[26] S. Humayun. ,B. Bano, Depth distribution of microbial diversity in Mono Lake, A meromictic soda lake in California N. Appl. Environ. Microbiol 69,2008, 1030-1042.

[27] A. Walkley and I. A Black, An examination of the degtiareff method for determining soil organic matter and a proposed modification of the chromic acid titration method, Soil Science, 37,1934, 29-38.

[28] APHA (American Public Health Association), Standard methods for examination of water and waste water, $18^{\text {th }}$ edition, 1992 , American Public Health Association, Washington DC.

[29] P. Bhattacharya, A.C. Samal, J. Majumdar, \& S.C. Santra, Accumulation of arsenic and its distribution in rice plant (ory za sativa L.) in gangetic west Bengal, India, .Paddy and Water Environment, 8(1), 2010, 63-70.

[30] M. M Hossain, M. A Sattar, M. A. Hashem and M. R Islam, Arsenic status at different depths in some soil of Bangladesh, J. Biological Sci., 1, 2003, 1116-1119

[31] R.N Krieg, Bergey's Manual of Systematic Bacteriology. Williams \& Wilkins, Baltimore, 1984, 837-942.

[32] H. Ohba and N. Owa, Isolation and Identification of Sulfur- oxidizing Bacteria from the Buried Layer Containing Reduced Sulfur Compounds of a Paddy Field on Sado Island in Niigata Prefecture, Bull. Facul. Agric. Niigata Univ, 58(1), $2005,55-61$.

[33]. M. M. Rahman, M. K. Sengupta, S. Ahamed, U. K. Chowdhury, D. Lodh, A. Hossain, B. Das, N. Roy,. K. C. Saha, S. K. Palit, \& D. Chakraborti, Arsenic contamination of groundwater and its health impact on residents in a village in West Bengal, India, Bulletin of the World Health Organization, 2005, 83 (1).

[34] M.Sadiq, Arsenic chemistry in soils: an overview of thermodynamic predictions and field observations. Water, Air and Soil Pollution 93, 1997,117-136.

[35] R. Turpeinen, .Interactions between metals, microbes \& plants-bioremediation of arsenic \& lead contaminated soil. Academic dissertation in Env Ecology.2003.

[36] S.P.Bachate, L Cavalca, V Andreoni ,Arsenic-resistant bacteria isolated from agricultural soils of Bangladesh and characterization of arsenate-reducing strains. Journal of Applied Microbiology 107, 2009, 145-156.

[37] C.R. Jackson, K.G. Harrison and S.L. Dugas,. Enumeration and characterization of culturable arsenate resistant bacteria in a large estuary, Systematic Applied Microbiol., 28,2005, 727-734.

[38] Abdul Rehman, S. Awais Butt and Shahida Hasnain, Isolation and characterization of arsenite oxidizing Pseudomonas lubricans and its potential use in bioremediation of wastewater, African Journal of Biotechnology Vol. 9(10), 2010, pp. 1493-1498. 